\title{
Firm's value sustainability via accounting ratios: The case of Nigerian listed firms
}

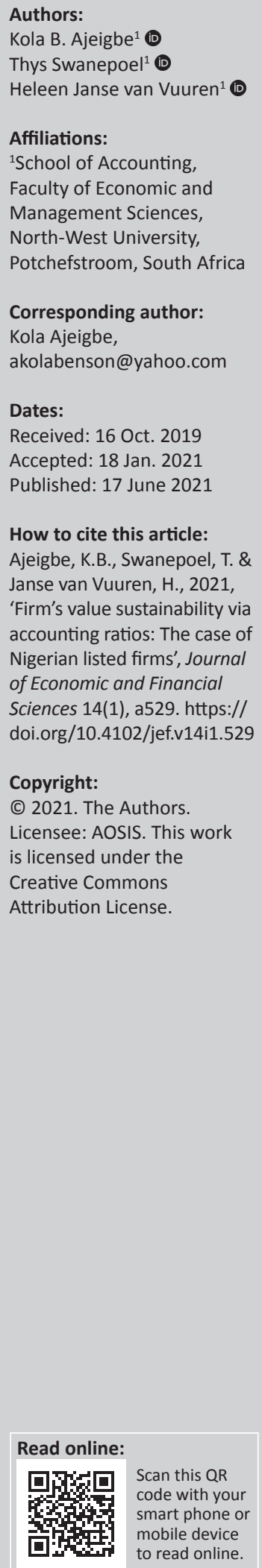

Orientation: The study highlights further use of accounting ratios by considering it as the main factor for value detecting, value enhancing and value sustainability tool. This is carried out by investigating the effect of accounting ratios on the performance of the listed firms in Nigeria.

Research purpose: The study examining the relationship between accounting ratios and firm value sustainability. It further studied the effect of accounting ratios on firm's value sustainability.

Motivation for the study: The study provoked an insight that accounting ratios should not only be used to analyse and interpret company's financial health but also be used as a tool that guides companies' operation for value sustainability.

Research approach/design and method: The study employed data retrieved from sampled listed firm's annual reports and centered the study on agency and signaling theories. The data were evaluated using descriptive analysis, Pool ordinary least square (OLS), random effect and panel generalised method of moment (GMM). Thirty firms representing all sectors except the financial sector from 2008 to 2017 were sampled using a stratified sampling method. The dependent variable is Tobin's q, whilst the explanatory variables are also proxy by accounting ratios.

Main findings: The study revealed that accounting ratios do not only affect and influence firm value but also help to detect if value had been created or not, as well as if the value created has been sustained over years. It further revealed a significant and positive relationship between ratios used in the study (current ratio, ROA, asset turnover, debt-equity ratio and earnings per share) and firm's value.

Practical/managerial implications: The study therefore recommended that a comprehensive accounting ratio that comprises both conventional accounting ratios and sustainability accounting ratios should be published. This should be published alongside with the firm's financial statement for ease of interpretation and determination of the yearly performance by any stakeholder who may want to interpret the report for an informed decision.

Contribution/value-add: It then stated that a before tax sustainability rate law should be enacted for easy determination of sustainability ratio. The study contributed to decision makers, Accounting Profession, Corporate Organizations and Government.

Keywords: firm value; accounting ratios; agency cost theory; signalling theory; value sustainability and sustainability ratios.

\section{Introduction}

Value sustainability is one of the problems that affect firms. So many firms liquidate today as a result of failure to sustain their value, which may be because of so many reasons such as lack of good governance, liquidity problem, stunted growth rate, etc. The accounting profession relies on sustainability because of conventional and fundamental 'going concern' concept. The 'going concern' presumed that a firm is expected to operate for the foreseeable future. Sustainability reporting has become important as stakeholders seek for more information about their investments. Sustainability report is broader than it was before as it considers other factors that can affect firm's survival within the firm and the environment in which the firm operates. Hence, there is a need for a sustainable growth rate that will not only help to survive but also to freely compete with any type of competitor in whatever industry such firm operates. Any firm that fails to grow may equally fail to sustain its value over years. The connection between accounting ratios and value sustainability is the yearly growth in firm's accounting ratios, which is a good measure 
of performance and a signal that value of such firm is sustained. However, Fonseka, Ramos and Tian (2012:481) stated that the growth rate of a firm can be dangerous if not well controlled. Therefore, yearly growth rate of performance that would help companies to achieve its primary objective of shareholders' value maximisation is needed for value sustainability (Bistrova \& Lace 2011:1305). Hence, value of firm needs to increase in such a manner that would meet the need of present generations and the generations to come (Brundtland Commission 1987:43; Redclift 2005:212). This is a practical decision that has to be taken strategically by the firm's managers to avert bankruptcy or corporate failure (Tuvadaratragool 2013:1)

Accounting ratios are the language of the business and the only tool that connects the chairman, CEO, board of directors, other management teams and other stakeholders together as argued by Enekwue (2015:18). Quality of accounting ratios have a direct link with the firm performance (Tuvadaratragool, 2013:1). Accounting ratios are employed to study past trends, a firm's present performance and may be given as an indication to project the future plans and policies. Zorn et al. (2018:1) studied financial ratios as indicators of economic sustainability in Switzerland. It could be inferred that accounting ratios serve as a practical means of monitoring, detecting value creation, improving performance and guiding the movement of firm value for sustainability (Wahlen \& Wieland 2011:92). The argument in the literature revolves around whether accounting ratios do have a positive influence on firm value or not. This was established by the findings of Komara, Ghozali and Januarti (2020:1), Karaca and Savsar (2012:56) and Kurtaran et al. (2015:35), who found conflicting results from their studies. The former found a positive and significant relationship, whilst the latter found a negative and insignificant impact. Ngwakwe and Ambe (2015:79) supported by Schaltegger (2015:4) argued that conventional accounting ratios are insufficient to predict a firm's value sustainability unless there is additional ecoratios that measure the firm's impact on its environment. Contrary to Schaltegger (2015:4) and Ngwakwe and Ambe (2015:79), this article sees conventional accounting ratios as sufficient to predict value sustainability of firms. A firm can remain sustainable if such firm maintains its balance sheet, an increasing level of net assets, net income, level of their shareholder's value and measure of sustainable social cost (Reinhardt 2000:3). The value in the statement of financial position can only be tested by accounting ratios whether they are increasing at an increasing rate or otherwise. Growth rate at a reducing rate is dangerous to firm as it can lead to corporate failure in the long run. Accounting ratio can also be represented by sustainable social cost. What the international financial reporting standard (IFRS) needs to do is to give a directive that certain percentage from firms annual before tax net income should be set aside for sustainable social cost. This will enable firms to determine a fixed percentage to inform of ratio from net income in the financial position of firms. By doing so, it can now be computed in value or ratio. This should be set aside for yearly sustainable development to determine sustainable social cost. Also, it will clear the argument that accounting ratios are insufficient to predict value sustainability and that accounting ratios can be used as a value detecting, value enhancing and value sustaining tool for strategic decision making (Ra'edmasa'deh et al. 2015:135). As Corporate Value Sustainability can only be detected, measured and its integration can be determined through Accounting ratios. The study also sees accounting ratios as language of the business and as a sustainability reporting requirement that every firm must sufficiently employ so that it can be used to assess and determine total value sustainability of a firm (Wahlen \& Wieland 2011:92). Therefore, accounting ratios are considered as tools in the hands of managers and other board of directors to carry out surgical operations on every firm and to take decisions relating to sustainability of such firm. This is because accounting ratios provide total summary information about the financial status and activities of the firm for useful accounting information. The quality of accounting ratios derived from a given financial statement at the end of a given financial year helps investors and other stakeholders to evaluate the firm's management efficiency and effectiveness on how the firm is managed in terms of its operations, management and profitability. This is because accounting ratios expose the management, help managers to forecast, plan, correct and help to determine the strengths and weak points of the firm's operations. Enekwue (2015:18) posited that accounting ratios are the language of the business and the only tool that connects the chairman, CEO, board of directors, other management teams and other stakeholders together. Therefore, it could be inferred that accounting ratios are a practical means of monitoring performance, maintaining value and sustaining growth of firms (Abdulraheem 2004:1; Baba 2013:1; Komara et al. 2020:1).

Realistically, assessment of firm's sustainability at country based, Nigeria listed firms complied with the IAS 1 directive as directors are mandated to report ongoing concern and sustainability of their firms in the note to the financial statement. However, the overall economic performance and other sustainability social performance of the listed firms ultimately depend on how reliable the information in the annual report is (Tsegba, Semberfan \& Tyokoso 2017). Therefore, sustainability is ultimately linked to the governance by the firm's directors and overall performance of the firm. This article therefore examined accounting ratios and the firm's value sustainability and further studied the relationship between accounting ratios and value sustainability. The next stage of this article is to establish the problem statement followed by related literature and the theoretical background. This is followed by related concepts, methodology, results of the analysis and conclusion, which are presented in an orderly manner.

The failure and collapse of firms around the world have increased the interest of researchers in determining the reasons why some promising corporations are failing despite their robust annual financial reports. Accounting ratios help to glean information from annual published financial 
statements and to detect whether value had been created through a firm's operation or not. This calls for the management and directors of firms to be more careful in their operations and to be more transparent and accountable for all their business activities. It also calls for them to be more active in establishing more models relating to accounting ratios in terms of governance that enhance firms' value in order to put an end to failure of corporate organisations around the world. One of the concepts that lead to good accounting ratios is to have good internal control and good governance in place. In fact, poor accounting ratios are a product of bad governance, thus managers introduce cosmetic accounting by window dressing financial records in order to impress the shareholders of firms and other interested stakeholders (Enekwue 2015:18). Yearly panel biting and inflating of financial record led to the failure of many promising businesses (Enron Case 2002; Intercontinental and Oceanic bank of Nigeria 2011; KPMG South Africa 2018 scandal). Therefore, as good as accounting ratios are, they give misleading results where the financial records fail to display the true financial records of the firm's operations. Prior studies on accounting ratios tend towards analysis and interpretation of businesses and to disclose the financial health of firms (Ra'edmasa'deh et al. 2015:135). Another problem is why most promising firms failed to sustain and improve the value created over years, despite their robust past years' financial data. Another gap is that research on accounting ratios and value sustainability in the global literature is very few and the topic still needs to be researched. Enekwue (2015:18) stated that most prior studies on accounting ratios and firm values dwell on two sectors only (financial and manufacturing sectors). Therefore, this article intends to fill all these gaps by examining the influence of accounting ratios on the value of firms and further looking at the relationship between accounting ratios and firm value sustainability. It should be noted that the study considers all the sectors except financial sectors because of the peculiarity of financial statements.

\section{Related literature, theories and concepts}

Studies around this topic mostly based their research on multitheoretical framework such as studies of the following scholars: Loh, Thomas and Wang (2017:3); Abdullah and Valentine (2009:88). This study equally employed the same structure by combining two theories, namely agency and signalling theory. Agency cost affects firm's value and if agency cost is not well controlled, it can hinder firm's value in the long run. The greater the cost of capital the lower the firm's returns (Correia et al. 2019). On the other hand, accounting ratios signal to the entire stakeholders (Tuvadaratragool 2013:1) about the performance of a firm and through the help of accounting ratios analysis, value sustainability growth rate can be determined. Accounting ratios that are sustainable in nature will continue to increase at an increasing rate yearly and this will always be a source of signal to investors. As agency's cost reduces yearly, accounting ratios will continue to increase and the firm will continue to grow in value. Yearly increase in accounting ratios automatically speaks well of the firm to the stakeholders and improves the value of the shareholders (Komara et al. 2020:1). Hence, value sustainability is achieved through yearly growth in ratios.

Extant studies were reviewed to discover existing gaps in the literature in relation to this study and it was discovered that there are few studies on accounting ratios and value sustainability in the world literature and in the Nigerian context. Martani and Khairurizka (2009:44) determined the effect of accounting information on stock yield. Data covering 4 years from 2003 to 2006 were retrieved from firms in Indonesia's stock market and multiple linear regression was employed for the study. Results revealed a positive influence between total asset and abnormal yield. The study also revealed that both market adjusted yield and cumulative yield are positively related with all the accounting ratios employed in the study. Birgili and Duzer (2010:74) examined financial ratios and their effects on firm value by using panel data of 58 firms indexed in IMKB-100 between 2001 and 2006. Results from all ratios on the liquidity, financial and market ratios group were statistically significant to firm value. However, part of the profitability and activity ratios influences firm value significantly, whilst others do not. Precisely, it reveals that gross profit margin, current ratio, cash ratio, debt-equity, asset turnover, current asset turnover, Return on Equity (ROE) and market to book value Price Earnings Ratio (P/E) ratio and Earnings Per Share (EPS) affect firm value positively, whilst other ratios such as the quick ratio, operating profitability, net profit margin Return on Asset (ROA), etc have an adverse influence on firm value. Karaca and Savsar (2012:56) studied accounting ratios and their effect on firm value. Panel data retrieved from 36 firms' annual reports covering different sectors from 2002 to 2009 were analysed. Firm value was employed as dependent variable, whilst accounting ratios were used as explanatory variables. Findings revealed that whilst both firm value and receivables turnover are positively and significantly related, $\mathrm{ROE}$ and inventory turnover are significant and inversely related; however, no relationship was discovered amongst other financial ratios.

Fonseka et al. (2012:481) studied the most appropriate sustainable growth rate model for managers and researchers by analysing the two sustainable growth models, namely Higgins model and the Van Horne model. Fonseka et al. (2012:481) found that these models are appropriate for both manager and researcher. Hernadi (2012:23) studied green accounting for corporate sustainability by analysing the different approaches to corporate sustainability. Hernadi (2012:23) suggested the reinterpretation of going concern principle and green accounting to sustainability accounting. Aydemir, Ögel and Demirtaş (2012:277) employed panel data amongst 73 manufacturing firms listed in Istanbul Menkul Kiymetler Borsasi (Istanbul Stock Exchange) (IMKB) from 1990 to 2009 to determine whether accounting ratios and firm value are related. The result shows a positive effect of accounting ratios (leverage, profitability and liquidity ratios) 
on stock return. However, it was revealed that the activity ratios do not affect stock earnings. Gramlich and Finster (2013:631) analysed the relationship between corporate sustainability and corporate risk. Granmlish and Finster (2013) employed risk and return, standard deviation and coefficient of variation and found no clear evidence between companies with high degree of sustainability and with high impact of risk. Rajhans and Kawalpreet (2013:1) investigated how firm value could be created. Evidence from numerous studies revealed that all financial variables used affect firm's value. Data retrieved from published financial statements of sampled listed firms on the Bombay stock exchange between 2002 and 2011were employed. Stationarity of the data were tested by conducting a panel unit root test and later statistical analysis using pooled ordinary least square (OLS). Findings revealed an inverse relationship between capital structure and firm value, whilst a positive and significant impact was revealed between WACC and firm worth. Baba (2013:1) also examined accounting ratios and the value of firms in Malaysia with the use of regression analysis. Whilst the study revealed a significant result between firm value and various accounting ratios, it also recommended the inclusion of more accounting ratios in the annual reports of firms. Asiri and Hameed (2014:1) also assessed how ratios explained firm value using firms in Bahrain from 1995 to 2013. Pooled time series data were employed comprising 646 firms and later regressed. The article found a significant effect between market value and firm size. Kurtaran et al. (2015:35) examined accounting ratios and the value of the firm. The study covered 45 firms that were consistently in the BITS-100 index between 2008 and 2012 and that data can be accessed regularly. Ordinary least square data revealed two results: whilst current ratio and firm value are significant and inversely related, the relationship with other ratios was not statistically explained. Ngwakwe and Ambe (2015:79) studied 'eco-ratio analysis' in business sustainability performance measurement by suggesting eco-ratio as a linkage between environmental performance and normal conventional firm's performance. Sevim (2016:221) investigated the relationship between stock yields and accounting ratios for 32 manufacturing firms' index in top 100 manufacturing on the British Stock Market (BIST-100). Data between 2001 and 2014 with panel data were analysed and results showed a statistically significant and negative effect of inventory turnover, account receivable turnover and tangible asset turnover on stock returns. However, short debt to total debt ratio influences stock return positively. The influence of other types of ratios such as liquidity, profitability activity and leverage on stock returns is not statistically significant. Karakus and Bozkurt (2017:27) studied financial ratios and some microeconomic variables that affect firm value through panel data analysis. The study retrieved data from 58 firms of the BIST-100 index from 2006 to 2015. An inverse result was revealed between stock returns and debt ratio, whilst working capital turnover ratio and ROA and the micro economic variables affect stock returns positively and significantly. Loh et al. (2017:1) investigated the relationship between sustainability reporting and firm value in Singapore and concluded that sustainability reporting is positively related to market value. Zorn et al. (2018:1) studied financial ratios as indicators of economic sustainability in Swiss. They employed Spearman correlation analysis and the result revealed mostly positive correlations.

Summary of the review revealed that the majority of the researchers on accounting ratios and value sustainability agree that accounting ratios have strong influence on value sustainability. The connection between accounting ratios and value sustainability is the yearly growth in firm's accounting ratios, which is a good measure of performance and a signal that value of such firm is sustained. Zabolotnyy and Wasilewski (2019:3) buttressed this by saying that financially sustainable companies demonstrated higher accounting ratios such as liquidity ratio and solvency ratio. International Accounting Standards (IAS) 1 also mandated sustainability reporting to improve level of accountability and transparency by directors of companies.

\section{Concept of accounting ratio}

An accounting ratio is an arithmetical expression, that is, relationship of one number to another in the form of a percentage. The accounting ratio is a nexus, link and signal between management and shareholders and all other users of financial statement (Enekwue 2015:18).

\section{Accounting ratio and value sustainability}

It has been discovered nowadays that shareholders and other stakeholders especially investors are not only demanding accountability and transparency but also sustainability of the value created by their firm. Today, as part of firms' annual report in the note to the account, directors are mandated to make sustainability report of their firm as an answer to stakeholders' request (IAS 1). Value sustainability becomes important for all firms to remain alive. It is one thing for firm to create value but it is another thing for that firm to sustain that value created. This study sees accounting ratios as the nexus between value created by a firm and value sustained by that firm. Value sustainability can be divided into two parts: internal and external. This is further subdivided into financial and non-financial value. Financial type is related to internal value whilst non-financial type is also related to external value. External value of a firm can be likened to the firm's value of goodwill and other fictitious or non-visible assets and the firm's corporate social responsibility. Whichever way one views a firm's value, it can be quantified by accounting ratios. The big question is what relationship accounting ratios have with value sustainability? Accounting ratios improve communication with stakeholders (Enekwue 2015:18), corporate transparency and sustainability reporting (Ngwakwe \& Ambe 2015:79). Sustainability reporting is a measure of firm's performance in relation to its environment and approach to know whether going concern of a firm is threatened or not. Reinhardt (2000:3) stated that value sustainability can be measured when firm value such as net asset, net income or as a measure of level of social cost maintain or continue to increase at a steady increasing rate. However, 


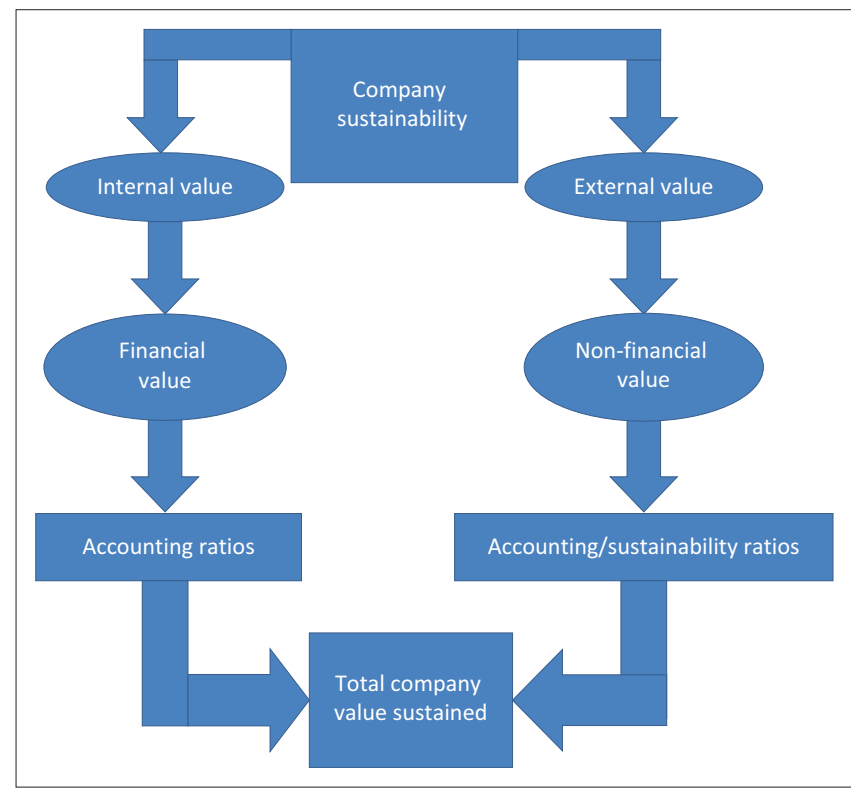

FIGURE 1: The relationship between accounting ratios and value sustainability.

value sustainability determination involves both financial and non-financial measure of firm's performance. Manager can only determine how value is created and sustained through calculation of certain accounting ratios from annual report. Higgins 1977, 1981 and Van Horne 1987 developed a sustainable growth model through four accounting ratios (Fonseka et al. 2012:481). The given explanation is represented in Figure 1, which explains the relationship between accounting ratios and firm value sustainability in a better way.

In spite of all the disadvantages that surround accounting ratios, it is still the fast, best, quantitative and comprehensive way of analysing firm performance. However, this study discovered that the best way of sustaining firm's value is by employing accounting ratios and economic value added with the use of information in the financial statements. Those accounting ratios are ROCE, Return on Net Asset (RONA) and they can be used to detect the value created by the firm over time. This is carried out by comparing the value computed by those ratios with the firm's WACC over the years. It is referred to as the economic value added approach and it is simply a division of profit after tax by the net operating assets $\left(\frac{\text { Net Operating Profit After Tax (NOPAT) }}{\text { Operating asset }}\right)$. Therefore, in line with economic value added, Return on Capital Employed (ROCE), Return on Invested Capital (ROIC) or Return on Asset (ROA) are defined using net operating assets or invested capital and then compared with the firm's Weighted Average Cost of Capital (WACC). The average cost of capital of a firm pays on all its sources of finance is called WACC. The decision is therefore, according to Correia et al. (2019), if ROCE, ROIC or ROA exceed WACC; it means that what the firm generated from investment is greater than its invested capital that it would need to pay back to the debt and equity holders. It then means value has been created. If otherwise, when WACC exceeds ROA, ROCE and ROIC, it is a serious issue and bad signal to the firm because value has been destroyed. ROA was therefore employed in the analysis as one of the accounting

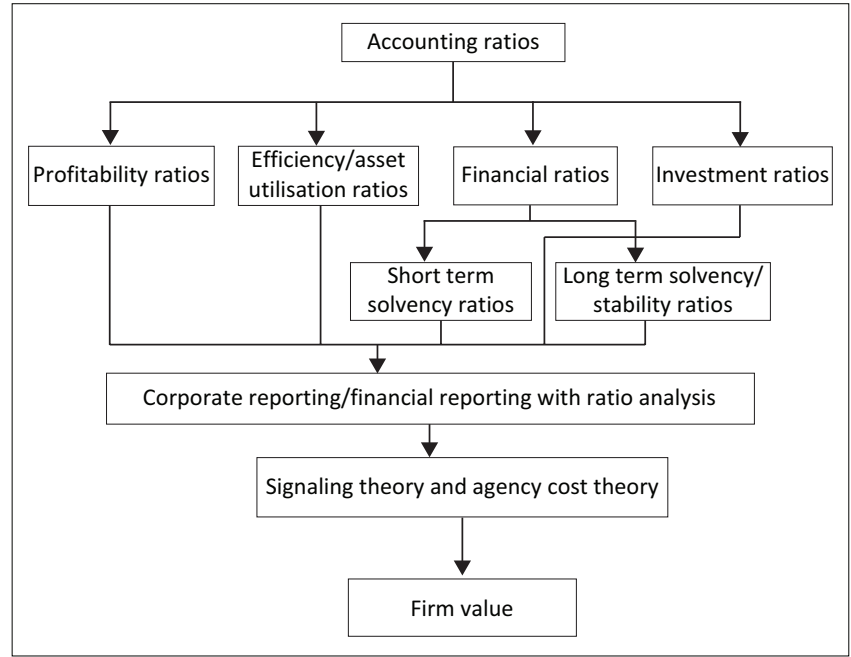

FIGURE 2: Interaction between accounting ratios and firm's value.

ratios employed to determine whether accounting ratios affect firm value or not. Shareholders and other stakeholders need information relating to how the value of their firms could be improved and sustained.

There are two types of users of financial information: internal users and external users, and there is always information asymmetry between them. External users obtain information through the published financial statements of the firm, especially through reported ratios attached to the report. However, ratios that detect whether firms retain their values are very important for continuity and for decision-making. This is the main reason why financial statement should possess a fair representation of the firm's affair and provide assurance that financial statements are a true representation of the firm's financial activities, as debated by Ingram and Albright (2007:1) and Asiri (2015:2). McLeaney and Atrill (2005), Ingram and Albright (2007:1) stated that accounting ratios are a simple and fast means of interpreting financial statements to examine a firm's financial health. Accounting ratios therefore affect firm value because they can reveal the strengths and weaknesses and the areas that need serious attention. On the other hand, if the financial statement is window dressed, accounting ratios provide misleading and harmful information that affects decision-making. When investors are taking their investing decision of where and what type of investment to embark on with their resources, accounting ratio analysis of both present and past financial position would be the basis of taking rightful decisions and of forecasting their impending performance as contended by Wahlen and Wieland (2011:89); Lev, Li and Sougiannis (2010:779) as cited by Asiri (2015:2); Užik and Šoltés (2009:52) as also cited by Malikova and Branbec (2010:79). Figure 2 depicts the conceptual framework of how accounting ratios can help to sustain firm's value following the work of Zorn et al. (2018:6) with little modification:

\section{Interpretation of the structure}

Figure 2 depicts the association amidst the financial strength of a firm as reflected by accounting ratios and firm's value. The fundamental theory for this model is signalling and 
agency cost, which relate that the higher the cost of capital, the lesser the firm's value. This will automatically result in low accounting ratios. Management tends to improve on the quality of governance in order to reduce the cost of capital, which has a direct link to better and higher accounting ratios and increases firm value in the long run. The computed ratios provide a signal to the management of an organisation to know the right decision to take at any given time, for better management, for smooth running of the business and for investing decisions by other stakeholders. Accounting ratios are used to access and define the value of any firm at any given time, predicting the future firm value, as well as to access corporate governance (i.e. the quality of work carried out by the management by employing the values in the financial statements.). Good corporate governance leads to better accounting ratios, and can amongst other factors (economic and financial stability), result in higher firm value. Firm value is created through the effectiveness of the management and the efficient use of resources at their disposal. Accounting ratios are the tool in the hand of accountants to determine the quality of governance operated by the management and to determine the level at which value of firms has been sustained. Internal and external control is to mandate the director to always publish accounting ratios alongside financial report statements as part of notes to the accounts. Prior studies have revealed that a combination of Accounting ratios and corporate governance makes the prediction model better than accounting ratios alone (Liang et al. 2016:561). If comprehensive components of ratios are computed alongside the annual report, a true picture of the firm is shown to all stakeholders for informed decision-making. From the given structure (Figure 1), this study groups accounting ratios into four parts, namely profitability ratios, asset or efficiency ratios, financial ratios and investment ratios following the work of Zorn et al. (2018:6) with little modification. The modification is based on the structure and the grouping of ratios. Whilst this study grouped ratios into four; Zorn et al. (2018:6) grouped theirs into five, namely profitability, liquidity, financial efficiency, stability and solvency ratios. However, grouping does not matter, what matters is interpretation or uses. Financial ratios are subdivided into two: short-term liquidity ratios and longterm solvency or stability ratios and they tend towards achieving good firm value. The interaction of all these ratios will surely reveal whether the going concern of the company is threatened and whether or not good corporate governance is practiced.

\section{Data and methodology}

This study only considered secondary data, which was retrieved from the firm's annual reports. The study adopted E-views 9.0 to analyse the data based on a stratified and convenience sampling method. For the purpose of this study, each sector was considered as a stratum and all sectors were considered except the financial sector because of the peculiarity of their financial statements. Firms that had their up-to-date data online were given priority, with at least one firm representing each sector. The dependent variable of the study is firm's value, which is represented by Tobin's q, and accounting ratios are independent variables. Each ratio was computed from the information in the annual reports and at least one ratio represents each classification. In this study firms with 10 years up-to-date financial statement at the Nigeria Stock Exchange Fact Sheet were being selected for this purpose. The justification for selecting this period was that it reflects the corporate governance practices of firms after these listed companies in the Nigeria Stock Exchange (NSE) were obliged to apply the rules of corporate governance in 2003 in Nigeria.

\section{Model specification on the effect of accounting ratios on the firm value of selected listed firms in Nigeria}

This section presents the empirical model that expresses the linear association between accounting ratio variables and the firm's value of the sampled firms. The dependent variable is firm's value and that of accounting ratios variables are:

ROA, asset turnover (ASST), EPS, quick ratio (QR), debt-equity ratio (DER). The linear model is stated below, following the work of Karaca and Savsar (2012):

$\mathrm{FV}_{\mathrm{it}}=\alpha_{1}+\beta_{1} \mathrm{X}_{1 \mathrm{it}}+\beta_{2} \mathrm{X}_{2 \mathrm{it}}+\beta_{3} \mathrm{X}_{3 \mathrm{it}} \ldots \ldots \ldots \ldots \ldots \ldots \ldots \beta_{\mathrm{n}} \mathrm{X}_{\mathrm{nit}}+\varepsilon_{\mathrm{it}} \quad$ [Eqn 1]

Accounting ratios are further incorporated into the given model to arrive at the following model:

$\mathrm{Q}_{\mathrm{it}}=\alpha_{1}+\beta_{1} \mathrm{ROA}_{\mathrm{it}}+\beta_{2} \mathrm{ASST}_{\mathrm{it}}+\beta_{3} \mathrm{EPS}_{\mathrm{it}}+\beta_{4} \mathrm{DER}_{\mathrm{it}}+\beta_{5} \mathrm{CR}_{\mathrm{it}}+\varepsilon_{\mathrm{it}}$ [Eqn 2]

where $F V$ and $Q_{i t}$ represent firm's value (dependent variable) and $\alpha_{0}$ is the intercept coefficient of the level of performance of the firm and $\beta_{1}, \beta_{2} \ldots$ are the parameters used in the model that represent the slope of each variable,

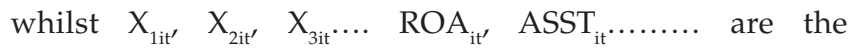
explanatory variables used to proxy accounting ratios and $\varepsilon_{\text {it }}$ represents the error term. The 'it' in the model suggested that the work employed time series and cross-sectional data for the study.

\section{Empirical results: Descriptive analysis}

To examine the relationship between accounting ratios and firm's value sustainability, we start with the analysis of the descriptive statistics of all the variables. This provides information about the measures of central tendencies such as mean, median and the minimum and maximum values. The mean value measures the average value of all the variables used, whilst the median measures the middle value. In addition, the descriptive statistics also provide information about the measures of dispersion such as standard deviations, skewness, kurtosis and Jarque-Bera and the probability of Jarque-Bera. Standard deviation explains the deviation of the value of each of the variables from the mean. Whilst skewness measures the shape of the distribution, kurtosis measures the peakedness of the distribution. Jarque-Bera test and its probability are 
used to confirm the validity or otherwise of the normal distribution. The descriptive statistics result is presented in Table 1: mean and median values of all the variables revealed that they are within their minimum and maximum values. This implies that all variables displayed a high level of consistency within the study period. In addition, by comparing the values of standard deviation of all the variables with their respective mean values, it can be deduced that current ratio, Tobin's-q, ROA, asset turnover ratio, EPS and debt-equity ratio are stable over the study period as their standard deviation values $(1.63,7.37,8.88$, $21.88,21.88$ and 20.65$)$ are higher than their mean values $(1.15,1.72,5.58,1.17,1.17$ and 4.68), respectively. Furthermore, results showed that two variables used in the study: Tobin's q and current ratio, were positively skewed whilst ROA, DER, asset turnover and EPS were negatively skewed. This result is based on the report of the skewness result. Another important feature of the data is kurtosis, which measures the peakedness of the shape of the distribution. Based on the descriptive result, asset turnover ratio, current asset and debt-equity ratio are leptokurtic, that is, they have extremely high height. Tobin's q and EPS are platokurtic, whilst the shape of ROA variables is mesokurtic, that is, flat-top. Finally, JarqueBera results and its statistics showed that the null hypothesis of normal distribution is rejected at $1 \%$. This is not unexpected because of the heterogeneous nature of the panel data and the number of years the data cover, which is less than 30. Also, the shape of all the variables is normal as the values of the skewness of all variables are less than one, except Tobin's $q$ and current ratio that are greater than one.

\section{Correlation matrix result}

The next step examined the degree of association amongst the variables because a high level of correlation between two independent variables will result in a multicollinearity. To verify this claim, the study adopted a correlation matrix and results are presented in Table 2. In addition, the probability values that confirm the significance of the relationships are included. Results showed that there is no strong relationship amongst some variables as their correlation coefficients are less than 0.5 , whilst there is strong relationship amongst DER and Tobin's q; current ratio and firm value; asset turnover and firm value, asset turnover and current ratio and EPS and DER where their coefficients are greater than 0.5. This implies that the two variables must not be included in the same regression. The result is significant at $1 \%$. Based on the direction of relationship amongst the variables, an inverse relationship exists between asset turnover and ROA; DER and asset turnover; current ratio and firm value; DER and firm value and asset turnover and current ratio. Whilst the relationship between ROA and DER; ROA and EPS and asset turnover and DER is significant at thislevel; all other variables have positive relationships. Whilst some are significant, others are not. In general, the regression result

TABLE 1: Descriptive statistics.

\begin{tabular}{|c|c|c|c|c|c|c|}
\hline Variables & Tobin-Q & Current ratio & ROA & Asset turn over ratio & Debt-equity ratio & Earnings per share \\
\hline Mean & 1.154466 & 1.724198 & 5.850229 & 1.176374 & 1.176374 & 4.686718 \\
\hline Median & 0.850000 & 1.100000 & 4.615000 & 1.285000 & 1.285000 & 1.955000 \\
\hline Maximum & 19.39000 & 120.0000 & 29.00000 & 36.82000 & 36.82000 & 87.16000 \\
\hline Minimum & 0.050000 & 0.000000 & -43.20000 & -343.1700 & -343.1700 & -240.0000 \\
\hline s.d. & 1.630970 & 7.374022 & 8.886839 & 21.88386 & 21.88386 & 20.65425 \\
\hline Skewness & 8.352585 & 15.84018 & -0.735075 & -14.89988 & -14.89988 & -6.109851 \\
\hline Kurtosis & 86.06692 & 254.5585 & 8.198788 & 235.8536 & 235.8536 & 79.81531 \\
\hline Jarque-Bera test & 78372.67 & 701781.5 & 318.6437 & 11637.99 & 601604.7 & 66044.89 \\
\hline Probability & 0.000000 & 0.000000 & 0.000000 & 0.000000 & 0.000000 & 0.000000 \\
\hline Sum & 302.4700 & 451.7400 & 1532.760 & 672.6900 & 308.2100 & 1227.920 \\
\hline Sum Sq. Dev. & 694.2765 & 14192.19 & 20612.71 & 6593.251 & 124993.8 & 111342.1 \\
\hline Observations & 262 & 262 & 262 & 262 & 262 & 262 \\
\hline
\end{tabular}

ROA, return on asset; s.d., standard deviation; Sum, summation ; Sum Sq. Dev., sum of square deviation.

TABLE 2: Correlation matrix.

\begin{tabular}{|c|c|c|c|c|c|c|}
\hline Variables & TQ & Current ratio & ROA & Asset turn over & DER & EPS \\
\hline TQ & 1.000000 & - & - & - & - & - \\
\hline \multirow[t]{2}{*}{ CR } & -0.020420 & 1.000000 & - & - & - & - \\
\hline & 0.74 & - & - & - & - & - \\
\hline \multirow[t]{2}{*}{ ROA } & 0.153575 & 0.047773 & 1.000000 & - & - & - \\
\hline & $0.01 * *$ & 0.44 & - & - & - & - \\
\hline ASST & 0.011518 & -0.026165 & -0.128868 & 1.000000 & - & - \\
\hline \multirow[t]{2}{*}{ DER } & -0.005709 & 0.002489 & 0.213617 & -0.169840 & 1.000000 & - \\
\hline & 0.92 & 0.96 & $0.00 *$ & $0.00 *$ & - & - \\
\hline \multirow[t]{2}{*}{ EPS } & 0.158922 & 0.004759 & 0.326222 & 0.064775 & 0.033493 & 1.000000 \\
\hline & $0.01 * *$ & 0.93 & $0.00 *$ & 0.29 & 0.58 & - \\
\hline
\end{tabular}

Note: $* * *$ represent a level of significance at $1 \%$ and $5 \%$, respectively.

TQ, Tobin's Q; CR, current ratio; ROA, return on asset; ASST, asset turnover; DER, debt-equity ratio; EPS, earnings per share. 
may not be free of multi-collinearity as there is strong association amongst some of the independent variables employed.

\section{Unit root analysis}

Furthermore, one of the major problems of time series data is non-stationarity. For reliability of the result, a panel unit root test was conducted on the variables using three approaches (Im, Pesaran \& Chin 2003; Levin; Lin \& Chu; and Fisher PP). This is because there is contradictory result between the first two approaches (Im et al. 2003; and Levin, Lin \& Chu), which is against the rule-of-thumb that the two approaches must have the same result. In this case, the third approach, Fisher PP., was employed. From Table 3, results indicate that all the variables are stationary at $1 \%$ levels except DER that is stationary at $10 \%$ and EPS that is significant at $5 \%$ after the first difference. Therefore, the null hypothesis of non-stationarity was rejected and the table is presented here:

Having examined the stationarity level of all the variables, the next step is to confirm the existence of long-run relationships amongst them, which is the co-integration test. There are two approaches available for this test. The first is the Pedroni co-integration test, whilst the second one is the Kao residual co-integration test. Whilst Pedroni can handle seven variables at once, Kao residual can handle more than seven variables. As the variables are six together with the dependent variable, the study then employed the Pedroni co-integration test. The result is presented in Table 4. Results showed that there is a longrun relationship amongst the variables as the null hypothesis of no co-integration is rejected at a $1 \%$ level of significance.

\section{Ethical considerations}

Approval to conduct the study was received from the Economic and Management Sciences Research Ethics Committee North-West University (NWU-01374-19-A4).

\section{Result}

To achieve the objective using the model specified in Equation 2, three methods of estimation, namely pool OLS, random effect model and system-GMM, were employed. Table 5 depicts the results of the three estimations. From the table, five measures of accounting ratios, namely current ratio, ROA, DER, asset turnover ratio and EPS, together with Tobin's q as the dependent variables, were used. The choice of the given ratios was based on this grouping from the conceptual frame work and choice between fixed or random effect was also based on the result from Hausman's specification test. The estimation of pooled OLS and random effect is just for comparison purposes. Results from the pool OLS revealed that the debt-equity ratio and current ratio are inversely related to firm's value, whilst other variables are positively related to firm's value. Except ROA and EPS that are significant at a 10\% level of significance, all other variables are statistically insignificant.

Results of the random effect is similar to that of pool OLS. For the random effect, current ratio and debt-equity ratios are inversely related to firm values but not statistically significant whilst other variables are positive with statistically significant impacts. From the results as well, it can be deduced that both current ratio and debt- equity ratio as a proxy for accounting ratio are inversely related to firm value whilst debt-equity ratio has a positive influence on firm value. Mathematically, for pool OLS, a $1 \%$ increase in the current ratio and debt-equity ratio will increase firm's value by $0.66 \%$ and $0.59 \%$, respectively. For the random effect as well, a $1 \%$ increase in current asset

TABLE 3: Panel unit root test.

\begin{tabular}{|c|c|c|c|c|c|c|c|c|c|}
\hline \multirow[t]{2}{*}{ Variables } & \multicolumn{3}{|c|}{ Im et al. (2003) } & \multicolumn{3}{|c|}{ Levin Lin Chu } & \multicolumn{3}{|c|}{ Fisher PP } \\
\hline & Level & F.D & Remarks & Level & First. Diff & Rmk & Level & First dif & Rmk \\
\hline Tobi Q & $-10.7353 *$ & - & $I(0)$ & $-94.7535 *$ & - & $I(0)$ & - & - & - \\
\hline $\mathrm{CR}$ & $-2.51170^{*}$ & - & $I(0)$ & $-8.30052 *$ & - & $\mathrm{I}(0)$ & - & - & - \\
\hline ROA & $-3.43876^{*}$ & - & $\mathrm{I}(0)$ & $-27.5227 *$ & - & $I(0)$ & - & - & - \\
\hline ASST & $-5.16608^{*}$ & - & $\mathrm{I}(0)$ & $-16.0754 *$ & - & $\mathrm{I}(0)$ & - & - & - \\
\hline DER & $-1.41824 * * *$ & - & $I(0)$ & $-3.43571 *$ & - & $I(0)$ & - & - & - \\
\hline EPS & - & - & - & -0.48619 & $-8.11936 *$ & $\mathrm{I}(1)$ & 0.087 & $-2.027 * *$ & I(1) \\
\hline
\end{tabular}

Note: $*, * * \& * * *$ represent a level of significance at $1 \%, 5 \%$ and $10 \%$, respectively.

Var, variables (CR, ROA, ASST, DER, and EPS); F.D, first difference of all the variables; Rmk, remarks; Tobi Q, Tobin's Q; CR, current ratios; ROA, return on asset; ASST, asset turnover; DER, debt-equity ratio; EPS, earnings per share.

TABLE 4: Co-integration test.

\begin{tabular}{lccc}
\hline Variables & Statistic & Probability & Weighted \\
\cline { 3 - 4 } & & & Prob. \\
\hline Panel v-statistic & -3.922872 & 1.0000 & -3.272113 \\
Panel rho-statistic & 5.775807 & 1.0000 & 4.815575 \\
Panel PP-statistic & 1.284185 & 0.9005 & -5.333594 \\
Panel ADF-statistic & 5.110916 & 1.0000 & 1.0000 \\
Alternative hypothesis: Individual AR coefficients (between-dimension) & & 0.0000 \\
Group rho-statistic & 6.974951 & 1.0000 & 0.9301 \\
Group PP-statistic & -9.853178 & 0.0000 & - \\
Group ADF-statistic & 0.924141 & 0.8223 & - \\
\hline
\end{tabular}


TABLE 5: Dependent variable: Tobin $q$.

\begin{tabular}{lccc}
\hline Variables & Pool OLS & Random effect & GMM \\
\hline Constant & $0.978(0.00)^{*}$ & - & - \\
Tobin-q(-1) & - & - & $0.49(0.00)^{*}$ \\
Current ratio & $-0.005(0.66)$ & $-0.0007(0.95)$ & $0.07(0.00)^{*}$ \\
Return on assets & $0.022(0.06)^{* * *}$ & $0.020(0.12)$ & $0.002(0.00)^{*}$ \\
Asset turn over & $0.004(0.83)$ & $0.0005(0.98)$ & $0.015(0.00)^{*}$ \\
Debt-equity ratio & $-0.002(0.59)$ & $-0.001(0.65)$ & $0.003(0.018)^{* *}$ \\
Earnings per share & $0.009(0.07)^{* * *}$ & $0.003(0.49)$ & $0.003(0.00)^{*}$ \\
$R^{2}$ & 0.03 & 0.01 & - \\
Adj. $R^{2}$ & 0.02 & -0.004 & - \\
$F$-Statistic & $2.07(0.06)$ & $0.74(0.58)$ & - \\
Hausman's specification test & - & $8.09(0.15)$ & - \\
$J$-Statistic & - & - & 21.19 \\
Instrument rank & - & - & 27 \\
Cross-sections included & 27 & 27 & 27 \\
Total observation & 262 & 262 & 208 \\
\hline OSS, ordinary lest squar & & & \\
\hline
\end{tabular}

OLS, ordinary least square; GMM, generalised method of moment; Adj., adjusted.

and debt-equity ratio increases firm value by $0.95 \%$ and $0.65 \%$, respectively.

We further employed system-GMM as proposed by Arellano and Bover (1995) in order to control if there is any omitted variable and endogeneity problem. This estimator is also appropriate for large cross-sectional data set and small time series. The story is different for system-GMM results. All variables are positively and significantly related with firm value. According to the result, although the effect of impact displayed by all the accounting ratios is small, they all have a positive impact on firm's value. For instance, a 1\% increase in current ratio, ROA, asset turnover, DER and EPS increases the value of the firm by $0.07 \%, 0.002 \%, 0.015 \%, 0.003 \%$ and $0.003 \%$, respectively. In general, considering all accounting ratios used in this study, the study revealed that accounting ratios have positive and significant influence on firm's value. This infers that accounting ratios enhance and improve the value of the firm as it was proved in the literature (Asiri \& Hammed 2014; Aydemir et al. 2012; Baba 2013:1; Karaca \& Savsar 2015:56; Rajhans \& Kawalpreet 2013:70). In order to correct the problem of endogeneity, simultaneity and multi-collinearity, the lag of all the explanatory and dependent variables was used as instruments both at level and first difference. For the diagnostic test, the j-statistic that measures the validity of instrument used is presented in the table. The results confirmed the validity of the instruments and the conditions for using the approach.

From the given results, the findings of this study are as follows: that accounting ratios are a good factor within the context of value creation, value enhancing tool and value sustainability tool. This was established from the given results that revealed a positive and significant effect on firm's value. How accounting ratios can detect the value of a firm as revealed and conceptualised by the definition of ROCE in different forms, RONA and ROA can help to discover whether the value has been created. These ratios are very important in relation to value sustainability. Sustainability growth rate, firm's performance and value can be determined from firm's yearly performance by accounting ratios. As accounting ratios can measure sustainability rate, value sustainability and accounting ratios are closely related. The need for this is that shareholders and other investors are not only asking for accountability and transparency, but also sustainability of the value created by the firms annually. From the given analysis result, it was revealed that the two investors' ratios employed as part of the accounting ratios (ROA and EPS) are positive and significant at $10 \%$ and at $1 \%$ under pool OLS and GMM, respectively. It was also revealed that the value of the ROA was greater than WACC, considering the year under review. It was also found that the results support existing studies, which support that accounting ratios affect firm value positively. The results from the analysis revealed little positive effect on firm value. The real reason why some promising firms are folding up in Nigeria can therefore be attributed to a lack of close monitoring of a firm's ratios, as this would reveal the area of strength, weakness and even to know whether the value created is sustained. Therefore, this study contributes to knowledge by adding to the existing literature to fill the gap created in the Nigerian framework. Prior to this study, there had not been any work on accounting ratio and firm value in the Nigerian context and even if there is, it could either be very few or might even not cover all sectors like this study did. This study therefore further adds to the body of knowledge that accounting ratios affect firm value by helping management to detect whether the value had been created or not and whether the value created is sustained or not by providing a direction of what decision to take. Therefore, this study also clears the argument of whether or not accounting ratios affect firm value from the results of the analysis and there is close relationship between accounting ratios and value sustainability. The study hereby suggests that the management of organisations should always compute comprehensive ratios in order to detect areas that need urgent attention to guide against corporate failure.

\section{Conclusion}

In conclusion, this study looked into accounting ratios and the firm value sustainability by assessing the effect of ratios on firm value and examined if there is relationship between accounting ratios and value sustainability. Panel data analysis was constructed and the study employed system-GMM for the analysis. The hypothesis of the study $\mathrm{H1}$, which says 'accounting ratios have an effect on the firm value', is accepted by the results from the analysis. All accounting ratio variables used in this study have positively and statistically related to firm value. According to the result, although the effect of all the variables is small but they all have a positive impact. For instance, a $1 \%$ increase in current ratio, ROA, asset turnover, DER and EPS increases the value of the firm by $0.07 \%, 0.002 \%$, $0.015 \%, 0.003 \%$ and $0.003 \%$, respectively. However, small it may be, it is still a positive influence that means a lot to any firm. In general, considering all accounting ratios used 
in this study, the study revealed that accounting ratios have a positive and significant influence on the value of any firm. This infers that accounting ratios enhance and improve the value of the firms listed in Nigeria. In addition, value sustainability determination involves both financial and non-financial measure of firm performance. Managers can only determine how value is created and sustained through the calculation of certain accounting ratios from annual report. Some accounting ratios revealed the firm's rate of performance and these ratios can be employed to determine whether firms retain or loss value. Therefore, a close relationship between accounting ratios and value sustainability is confirmed. Zabolotnyy and Wasilewski (2019:3) buttressed this by saying financially sustainable companies demonstrated higher accounting ratios such as liquidity ratio and solvency ratio. IAS 1 also mandated sustainability reporting to improve level of accountability and transparency by directors of companies.

\section{Acknowledgements Competing interests}

The authors have declared that there is no competing interest.

\section{Authors' contributions}

All authors contribute equally to this work.

\section{Funding information}

This research received no grant from any funding agency in the public, commercial and not-for-profit organisation.

\section{Data availability}

Data used for this article were retrieved from companies' financial statements listed on the Nigerian Stock Exchange. There was no new data created.

\section{Disclaimer}

The views and opinions expressed in this article are those of the authors and do not necessarily reflect the official policy or position of any affiliated agency of the authors.

\section{References}

Abdullah, H. \& Valentine, B., 2009, 'Fundamental \& ethics theories of corporate governance', Middle Eastern Finance and Economic Journal 4, 88-96.

Abdulraheem, A., 2004, Ratio analysis as a measure of performance in the banking industry: A case study of selected banks in advances in management, A Publication of the Department of Business Administration, University of Ilorin, Ilorin, of the Depart
pp. $130-140$.

Albright, T.L. \& Ingram, R.W., 2007, Financial accounting: Information for decisions, Thomson/South-Western Learning publisher and Editor, London.

Arellano, M. \& Bover, O., 1995, 'Another look at the instrumental variable estimation of error-components models', Journal of Econometrics 68(1), 29-51. https://doi. org/10.1016/0304-4076(94)01642-D

Asiri, B.K., 2015, 'How investors perceive financial ratios at differen growth opportunities and financial leverages', Journal of Business Studies Quarterly 6(3), 1.

Asiri, B.K. \& Hamed, S.A., 2014, 'Financial ratio and firm's value in the Bahrain Bourse', Research Journal of Finance and Accounting 5(7), 1-10.
Aydemir, O., Ogel, S. \& Demirtaş, G., 2012, 'The Role of Financial Ratios in Determining the Stock Prices', Celal Bayar University Journal of the Faculty of Economics and Administrative Sciences 19(2), 278-288.

Baba, B.U., 2013, 'The effect of accounting ratios on firm's value: Evidence from Malaysian listed companies', Doctoral dissertation, Universiti Utara Malaysia.

Bartlett, B.D., 2012, 'The effect of corporate sustainability reporting on firm valuation', CMC Senior thesis, Claremont Mckenna College, Paper 489.

Birgili, E. \& Düzer, M., 2010, 'The relationship between the rates which are used in Financial fnalysis and firm value an application in Istanbul Stock Exchange', MUFAD Journal 46(1), 74-83.

Bistrova, J. \& Lace, N., 2011, 'The model of sustainable shareholder value', in Proceedings of the 17th International Business Information Management Association Conference, Orlando, pp. 1305-1315.

Correia, C., 2019, Financial management, Juta, Cape Town.

Enekwue, C.I., 2015, 'The relationship between financial ratio analysis and corporate profitability: A study of selected quoted oil and gas companies in Nigeria', European Journal of Accounting, Auditing and Finance Research 3(2), $17-34$

Fonseka, M.M., Ramos, C.G. \& Tian, G.L., 2012, 'The most appropriate sustainable growth rate model for managers and researchers', Journal of Applied Business Research (JABR) 28(3), 481-500. https://doi.org/10.19030/jabr.v28i3.6963

Hernadi, B.H., 2012, 'Green accounting for corporate sustainability', Theory, Methodology, Practice 8(2), 23.

Im, K.S., Pesaran, M.K. \& Shin, Y., 2003, 'Testing for unit roots in heterogeneous panels', Journal of Economics 115(1), 53-74. https://doi.org/10.1016/S03044076(03)00092-7

International Integrated Reporting Council (IIRC), 2020, International framework implementation feedback: Invitation to comment, International Integrated Reporting Council, London.

Karaca, S.S. \& Savsar, A., 2012, 'The effect of financial ratios on the firm value: Evidence from Turkey', Journal of Applied Economic Sciences 7(19), 56-63.

Karaca, S.S. \& Savsar, A., 2015, 'The effect of financial ratios on the firm value: Evidence from Turkey', Journal of Applied Economic Sciences (January 2012).

Karakus, R. \& Bozkurt, I., 2017, 'The effect of financial ratios and macroeconomics factors on firm value: An empirical analysis in Borsa Istanbul', in An International Conference on Social Issue and Economic Studies. 4th Multidisciplinary Conference, Prague, June 29-30, 2017, pp. 27-34.

Komara, A., Ghozali, I. \& Januarti, I., 2020, 'Examining the firm value based on signaling theory', in 1st International Conference on Accounting, Management and Entrepreneurship (ICAMER 2019), Indonesia, March, pp. 1-4.

Kurtaran, A., Turan Kurtaran, A., Kurtaran Çelik, M. \& Temizer, Z., 2015, 'Finansal Oranlar ile Firma Değeri Ilişskisi: BIST'te Bir Uygulama', Global Journal of Economics and Business Studies 4(8), 35-45.

Lev, B., Li, S. \& Sougiannis, T., 2010, 'The usefulness of accounting estimates for predicting cash flow and earnings', Review of Accounting Studies 15(4), 779-807. https://doi.org/10.1007/s11142-009-9107-6

Liang, D., Lu, C.C., Tsai, C.F. \& Shih, G.A., 2016, 'Financial ratios and corporate governance indicators in bankruptcy prediction: A comprehensive study', European Journal of Operational Research 252(2), 561-572. https://doi. org/10.1016/j.ejor.2016.01.012

Loh, L., Thomas, T. \& Wang, Y., 2017, 'Sustainability reporting and firm value: Evidence from Singapore-listed companies', Sustainability 9(11), 2112. https://doi. org/10.3390/su9112112

Malikova, O. \& Brabec, Z., 2012, 'The influence of a different accounting system on informative value of selected financial ratios', Technological and Economic Development of Economy 18(1), 149-163. https://doi.org/10.3846/20294913.20 12.661193

Martani, D.M. \& Khairurizka, R., 2009, 'The effect of financial ratios, firm size, and cash flow from operating activities in the interim report to the stock returns', Chinese Business Review 8(6), 44-55.

McLeaney, E., \& Atrill, P., 2005, Accounting an introduction, Prentice Hall, Harlow.

Ngwakwe, C.C. \& Ambe, C.M, 2015, "'Eco-Ratio Analysis" in Business sustainability performance measurement', Proceedings of the 1st World Business Council for Sustainability Development (WBCSD) and Environmental Sustainability management Network (EMAN), Joint international sustainability Accounting Symposium, Leuphana University, Geneva, pp. 79-83.

Pedroni, P., 1999, 'Critical values for co-integration tests in heterogeneous panels with multiple regressors', Oxford Bulletin of Economics and Statistics 61(1), 653-670. https://doi.org/10.1111/1468-0084.61.s1.14

Pedroni, P., 2004, 'Panel co-integration: Asymptotic and finite sample properties of pooled time series tests with an application to the PPP hypothesis', Econometric Theory 20(3), 597-625

Pesaran, M.H., 2007, 'A simple panel unit root test in the presence of cross-section dependence', Journal of Applied Econometrics 22(2), 265-312. https://doi. org/10.1002/jae.951

Ra'edmasa'deh, M, Tayeh, M., Al-Jarrah, I.M. \& Tarhini, A., 2015, 'Accounting vs marketbased measures of firm performance related to information technology investment', International Review of Social Sciences and Humanities 9(1), 129-145.

Rajhans, R.K. \& Kawalpreet, K., 2013, 'Financial determinants of firm's value: Evidence from Indian firms', International Journal of Business Economics \& Management Research 3(5), 70-76. 
Redclift, M., 2005, 'Sustainable development (1987-2005): An oxymoron comes of age', Sustainable Development 13(4), 212-227. https://doi.org/10.1002/sd.281

Reinhardt, F., 2000, 'Sustainability and the firm', Journal of Applied Analyst 30(3), 26-41. https://doi.org/10.1287/inte.30.3.26.11667

Sarbanes-Oxley Act, 2002, Public company accounting reform and investor protection, Public Law: No. 107-204, U.S. Congress, Washington, DC.

Schaltegger, S., 2015, Contribution to sustainability, what kind of information is needed, 2015, 'Eco-ratio analysis', in Business sustainability performance measurement, Proceedings of the WECSD and EMAN, Joint International Sustainability Accounting Symposium, Leuphana University, Geneva, pp. 79-83.

Sevim, U., 2016, 'İşletme Finansal Oranlarının Hisse Senedi Getirileri Üzerine Etkisi BIST 100 İmalat İ̧letmeleri Örneği', Eskişehir Osmangazi Üniversitesi iiBF Dergisi 11(2), 221-235.

Sinkin, C., Wright, C.J. \& Burnett, R.D., 2008, 'Eco-efficiency and firm value', Journal of Accounting and Public Policy 27(2), 167-176. https://doi.org/10.1016/j. jaccpubpol.2008.01.003

Tsegba, I.N., Semberfan, J. \& Tyokoso, G.M., 2017, 'Firm characteristics and compliance with international financial reporting standards (IFRS) by listed financial service companies in Nigeria', Applied Finance and Accounting 3(1), 83-93. https://doi. org/10.11114/afa.v3i1.2196
Tuvadaratragool, S., 2013, 'The role of financial ratios in signaling financial distress: Evidence from Thai listed companies', PhD dissertation, Southern Cross University Evidence
Lismore.

Užik, M. \& Šoltes, V., 2009, 'Vplyv zmeny ratingu na ceny spoločnosti obchodovanych na kapitalovom trhu', E\&M Ekonomie a Management 12(1), 49-56.

Wahlen, J.M. \& Wieland, M.M., 2011, 'Can financial statement analysis beat consensus analysts' recommendations?', Review of Accounting Studies 16(1), 89-115. https://doi.org/10.1007/s11142-010-9124-5

World Commission on Environment and Development and Brundtland, G.H., 1987, Presentation of the Report of the World Commission on Environment and Development to the Commission of the European Communities, the EC and EFTA Countries, 5 May 1987, World Commission on Environment and Development, Brussels.

Zabolotnyy, S. \& Wasilewski, M., 2019, 'The concept of financial sustainability measurement: A case of food companies from Northern Europe', Sustainability 11(18), 5139. https://doi.org/10.3390/su11185139

Zorn, A., Esteves, M., Baur, I. \& Lips, M., 2018, 'Financial ratios as indicators of economic sustainability: A quantitative analysis for Swiss dairy farms', Sustainability 10(8), 2942. https://doi.org/10.3390/su10082942 